\title{
Multiple extracellular signals are required for long-term oligodendrocyte
} \section{survival}

\author{
B. A. Barres ${ }^{1, \star}$, R. Schmid ${ }^{2}$, M. Sendnter ${ }^{2}$ and M. C. Raff ${ }^{1}$ \\ ${ }^{1}$ Medical Research Council Developmental Neurobiology Programme, Department of Biology, Medawar Building, University \\ College, London WC1E 6BT, UK \\ ${ }^{2}$ Max-Planck-Institute for Psychiatry, Department of Neurochemistry, 8033 Planegg-Martinsried, Germany
}

${ }^{*}$ Author for correspondence

\section{SUMMARY}

We showed previously that oligodendrocytes and their precursors require continuous signalling by protein trophic factors to avoid programmed cell death in culture. Here we show that three classes of such trophic factors promote oligodendrocyte survival in vitro: (1) insulin and insulin-like growth factors (IGFs), (2) neurotrophins, particularly neurotrophin-3 (NT-3), and (3) ciliary-neurotrophic factor (CNTF), leukemia inhibitory factor (LIF) and interleukin 6 (IL-6). A single factor, or combinations of factors within the same class, promote only short-term survival of oligodendrocytes and their precursors, while combinations of factors from different classes promote survival additively. Long-term survival of oligodendrocytes in vitro requires at least one factor from each class, suggesting that multiple signals may be required for long-term oligodendrocyte survival in vivo. We also show that CNTF promotes oligodendrocyte survival in vivo, that platelet-derived growth factor (PDGF) can promote the survival of oligodendrocyte precursors in vitro by acting on a novel, very high affinity PDGF receptor, and that, in addition to its effect on survival, NT-3 is a potent mitogen for oligodendrocyte precursor cells.

Key words: neurotrophins, programmed cell death, apoptosis, ciliary-neurotrophic factor, interleukin 6 , insulin, insulin-likegrowth factor I, platelet-derived growth factor, NT-3

\section{INTRODUCTION}

Some vertebrate cells require continuous signalling from other cells to avoid programmed cell death (Wyllie et al., 1984; Martin et al., 1988; Krypaniou and Isaacs, 1988; Williams et al., 1990; Koury and Bondurant, 1990; Cohen, 1991), and some naturally occurring cell deaths in vertebrates seem to reflect the presence of limiting amounts of survival factors (Levi-Montalcini, 1987; Purves, 1988; Barde, 1989). It is even possible that all vertebrate cells, other than blastomeres (Biggers et al., 1971), require such survival factors (Raff, 1992). Yet, despite its importance, there has been relatively little study of cell survival control compared to the great effort devoted to the study of cell proliferation control.

We recently showed that oligodendrocytes and their precursors require signals from other cells to survive in culture and that about $50 \%$ of newly formed oligodendrocytes produced in the developing rat optic nerve normally die, apparently as a result of a competition for limiting amounts of survival factors (Barres et al., 1992). In these studies, we found that both platelet-derived growth factor (PDGF) and insulin-like growth factors (IGFs) promote the survival of oligodendrocyte precursor cells in vitro, but that once the precursor cells stop dividing and begin to differentiate into oligodendrocytes, their specific survival requirements change: PDGF no longer promotes their survival, although IGFs still do.

These studies raised several questions. Are IGFs the only signalling molecules that promote oligodendrocyte survival? Are IGFs sufficient to promote long-term as well as short-term survival of oligodendrocytes? Which trophic factors regulate oligodendrocyte survival in vivo? In the present study, we have extended our observations on the control of oligodendrocyte survival. We show that the protein signalling molecules that promote oligodendrocyte survival in vitro fall into at least three classes. Whereas a single trophic factor promotes short-term survival, at least one factor from each class is required to promote long-term oligodendrocyte survival in vitro. We also show that one of the survival factors, CNTF, promotes oligodendrocyte survival in vivo, that PDGF promotes the survival of oligodendrocyte precursor cells in vitro at concentrations that are more than 200-fold lower than those required to stimulate these cells to synthesize DNA, and that NT-3, like PDGF, is a potent mitogen, as well as a potent survival factor, for the oligodendrocyte cell lineage. 


\section{MATERIALS AND METHODS}

\section{Animals and materials}

Sprague/Dawley (S/D) rats were obtained from the breeding colony of University College London. Recombinant human IGFs and mouse LIF were generously provided by Mats Lake of Kabigen and John Heath, respectively. Insulin was purchased from Sigma. Recombinant human PDGF-AA and PDGF-BB was purchased from Peprotech (NJ). Recombinant human Il-6 was purchased from R \& D Systems, Inc. Recombinant rat CNTF and mouse NT-3 were prepared as previously described (Stockli et al., 1989; Gotz et al., 1992). The CG-4 oligodendrocyte precursor cell line was provided by J. C. Louis (Louis et al., 1992).

\section{Purification of oligodendrocyte precursor cells and oligodendrocytes}

Oligodendrocytes and their precursors (O-2A progenitor cells) were each purified from postnatal rat optic nerve by sequential immunopanning as described previously (Barres et al., 1992). Briefly, an optic nerve cell suspension was prepared enzymatically with papain and the cells were passed sequentially over a series of Petri dishes coated with the following monoclonal antibodies: anti-RAN-2 (IgG; Bartlett et al., 1981), the O1 anti-galactocerebroside (GC) antibody (IgM; Sommer and Schachner, 1981, 1982), and A2B5 (IgM; Eisenbarth et al., 1979). The purified cells - oligodendrocytes from the $\mathrm{O} 1 \mathrm{dish}$ and oligodendrocyte precursor cells from the A2B5 dish - were removed with trypsin.

\section{Cell survival assay}

Approximately 5,000-10,000 purified oligodendrocytes or their precursor cells were cultured in 96-well plates (Falcon) in $100 \mu \mathrm{l}$ of a serum-free medium, containing Dulbecco's Modified Eagle's Medium (DMEM), bovine serum albumin (BSA), selenium, putrescine, thryoxine, tri-iodothyronine, transferrin, and progesterone (modified from Bottenstein and Sato, 1979, as previously described by Lillien and Raff, 1990; B-S medium), and the appropriate trophic factors. When tested individually, none of the components of the B-S medium promoted survival except for progesterone. In its absence, survival of oligodendrocytes after 3 days in culture in the absence of added peptide factors was approximately half that shown in Table 1 (that is about $10 \%$ instead of $22 \%$ ). The B-S medium was prepared with a highly purified, crystalline grade of BSA (Sigma, A4161) in order to avoid contaminating survival factors. It was important that the DMEM contained pyruvate $(1 \mathrm{mM})$, as we found that in its absence nearly all of the cells died within the first day or two of culture. The percentage of surviving cells was assessed after 3, 7, and 14 days by the MTT assay (see below). All values were normalized to the percentage of surviving cells at 12 hours after plating, which represented the percentage of cells that survived the purification procedure. This initial viability was generally between 85 and $90 \%$ and was never lower than $80 \%$.

The survival responses of the purified oligodendrocytes and purified oligodendrocyte precursor cells to each of the trophic factors used (except for NT-3 and PDGF) were indistinguishable, because, in the absence of mitogen, the oligodendrocyte precursor cells withdraw from the cell cycle and differentiate into oligodendrocytes within 24-48 hours (Barres et al., 1992). Thus, except for NT-3 and PDGF, we have pooled all of the data and have described the purified cells simply as oligodendrocytes. In experiments with NT-3, which, like PDGF but unlike the other factors tested, was found to be mitogenic for oligodendrocyte precursor cells, survival was assessed on newly formed oligodendrocytes, which do not divide in response to NT-3 (see Results). To prepare newly formed oligodendrocytes, purified oligodendrocyte precursor cells were cultured for 24 hours in high concentrations of insulin $(5 \mu \mathrm{g} / \mathrm{ml})$ to allow them to differentiate into oligodendrocytes before they were resuspended and tested, as described previously (Barres et al., 1992). In experiments with PDGF, survival was assessed on purified oligodendrocyte precursor cells.

\section{MTT survival assay}

The MTT survival assay was performed as described by Mosmann (1983). MTT (3-(4,5-dimethylthiazol-2-yl)-2,5-diphenyl tetrazolium bromide; Sigma) was dissolved in PBS at $5 \mathrm{mg} / \mathrm{ml}$ and sterilized by passage through a Millipore filter $(0.22 \mu \mathrm{m})$. This stock solution was added ( $10 \mu \mathrm{l}$ to $100 \mu \mathrm{l}$ well) to the cultures for 1 hour at $37^{\circ} \mathrm{C}$. Viable cells with active mitochondria cleave the tetrazolium ring to form a visible dark blue formazan reaction product. The percentage of viable cells in each well was counted by bright-field phase microscopy.

\section{Quantitation of DNA in optic nerves}

The amount of DNA in optic nerves was measured as described previously (Barres et al., 1992). Briefly, optic nerves were digested in a buffer containing TES (Tris-HCl $10 \mathrm{mM}$, EDTA $50 \mathrm{mM}$, SDS $0.1 \%)$ and proteinase $\mathrm{K}(200 \mu \mathrm{g} / \mathrm{ml})$ at $55^{\circ} \mathrm{C}$ for 36 hours. The amounts of DNA in the optic nerve digests were measured using the fluorimetric method of LaBarca and Paigen (1980; also see Brunk et al., 1979), which is based on the enhancement of fluorescence seen when the dye bisbenzimidazole (Hoechst 33258) binds to DNA. The DNA values were converted to cell number by dividing by $6.6 \mathrm{pg}$ of DNA per cell.

\section{Propidium iodide labelling of cryostat sections of optic nerve}

Postnatal rats were anesthetized with ether and perfused with $4 \%$ paraformaldehyde. The optic nerves were removed and incubated in $4 \%$ paraformaldehyde at $4^{\circ} \mathrm{C}$ overnight and transferred to $30 \%$ sucrose in PBS until equilibrated. The nerves were frozen in OCT and cut into $8 \mu \mathrm{m}$ longitudinal sections with a Bright cryostat. The sections were collected onto gelatinized glass microscope slides, air dried, post-fixed in $70 \%$ ethanol for 10 minutes at $-20^{\circ} \mathrm{C}$, and stained with propidium iodide $(4 \mu \mathrm{g} / \mathrm{ml})$ solution in MEM/Hepes containing DNAse-free RNAse A $(100 \mu \mathrm{g} / \mathrm{ml})$ for 30 minutes at $37^{\circ} \mathrm{C}$. The slides were washed three times in PBS and mounted in Citifluor (City University, London, UK).

The number of pyknotic nuclei per section was determined by averaging the number of pyknotic cells counted in five optic nerve sections per animal. Only clearly condensed or fragmented nuclei were counted as pyknotic. Most pyknotic nuclei were between 2 and $4 \mu \mathrm{m}$ in diameter, which was several times smaller than the thickness of the section $(8 \mu \mathrm{m})$.

\section{Bromodeoxyuridine (BrdU) incorporation and immunofluorescence staining}

To label cells in S phase, BrdU (10 $\mu \mathrm{M}$; Boehringer Mannheim), which is incorporated into replicating DNA (Gratzner, 1982), was added to the culture medium for 24 hours. After fixation with $4 \%$ paraformaldehyde for 90 seconds at room temperature, and a 15 minute incubation in 50\% goat serum containing 1\% BSA and $100 \mathrm{mM}$ L-lysine to block non-specific binding, cells were surface-stained, either with monoclonal anti-GC antibody (supernatant used at 1:1) followed by fluorescein-coupled goat antimouse IgG3 (Nordic; 1:100) or with A2B5 antibody (supernatant diluted 1:1) followed by fluorescein-coupled goat anti-mouse IgM (u chain specific, Accurate). Cells were post-fixed in $70 \%$ ethanol at $-20^{\circ} \mathrm{C}$ for 10 minutes, incubated in $2 \mathrm{~N} \mathrm{HCl}$ for 10 minutes to denature the nuclear DNA, followed by $0.1 \mathrm{M}$ sodium borate, $\mathrm{pH}$ 8.5 for 10 minutes. The cells were then incubated in $50 \%$ goat serum containing $0.4 \%$ Triton X-100 for 30 minutes and labelled with monoclonal anti-BrdU antibody (ascites, 1:100; Magaud et 
al., 1988), followed by rhodamine-coupled goat anti-mouse IgG1 (Nordic, 1:100). In some experiments, cells were stained with rabbit anti-GFAP antiserum (Pruss, 1979; diluted 1:100); in this case, the cells were fixed with acid-alcohol for 10 minutes at $-20^{\circ} \mathrm{C}$ and blocked with goat serum as above. The anti-GFAP antibodies were detected with fluorescein-coupled goat anti-rabbit $\operatorname{IgG}(\mathrm{H}+\mathrm{L}$ chain specific, Accurate). The coverslips were mounted in Citiflour on glass slides and sealed with nail varnish, examined in a Zeiss Universal fluoresence microscope, and photographed using Kodak Tri-X film (ASA 400).

Glial cell types were identified by their characteristic morphologies and antigenic phenotypes: astrocytes were labeled by anti-GFAP antiserum (Pruss, 1979), oligodendrocyte precursor cells by A2B5 antibody (Raff et al., 1983) and oligodendrocytes by anti-GC antibody (Ranscht et al., 1982).

\section{Preparation of stably transfected 293 cells that secrete CNTF}

The cDNA coding for the entire coding region of rat CNTF (600 bp) was cloned $3^{\prime}$ of a cDNA fragment coding for the first 20 amino acids of mouse nerve growth factor, as described previously (Sendnter et al., 1992). This construct was cloned into the pRcCMV expression vector (inVitroGen). Transfection of the human embryonic kidney cell line 293 was performed by the calcium phosphate method and stably transfected clones were selected with G418 for neomycin resistance. Single clones were picked, grown up and the supernatants of these clones screened for their ability to support the survival of embryonic day 8 chick ciliary neurons. As previously described for mouse D3 embryonic stem cells, more than $1000 \mathrm{TU}$ (corresponding to at least $1 \mathrm{ng}$ of CNTF) were detectable per $\mathrm{ml}$ of supernatant from confluent cultures from these cells, indicating that these cells efficiently synthesized and secreted CNTF.

\section{Transplantation of cell lines}

293 cells secreting CNTF were transplanted into the brain, as described previously for transfected COS cells (Barres et al., 1992). The cells were trypsinized in a $75 \mathrm{~cm}^{2}$ flask and washed as described above. They were resuspended in $1 \mathrm{ml}$ of Hepesbuffered Minimum Eagles's Medium (MEM/Hepes) and spun for 10 seconds at high speed in an Eppendorf microcentrifuge. The pellet was resuspended in MEM/Hepes to a concentration of 1 million cells per $3 \mu \mathrm{l}$. Under ether anesthesia, $3 \mu \mathrm{l}$ of the cell suspension was slowly injected through the right frontal skull into the subarachnoid space of postnatal rats, using a $10 \mu$ Hamilton syringe. The rats were killed after 4 days.

\section{RESULTS}

\section{Effects of insulin and IGFs on oligodendrocyte survival in vitro}

To determine the survival effects of different concentrations of insulin and IGFs on purified oligodendrocytes, we purified and cultured the cells in B-S serum-free medium (see Materials and methods), and assessed their survival after 3 days with the MTT assay, as described previously (Mosman, 1983; Barres et al., 1992). In the absence of added growth factors, the majority of the cells died within 3 days with the characteristic morphology of apoptosis within 3 days (Table 1). In the presence of plateau concentrations of IGF-1, IGF-2, or insulin, about two thirds of the cells survived for 3 days (Table 1). The concentration that promoted half-maximal survival (the $\mathrm{ED}_{50}$ ) was about
Table 1. Survival of purified oligodendrocytes in culture

\begin{tabular}{lcc}
\hline Factor & $\begin{array}{c}\text { \% Surviving } \\
\text { cells at 3D }\end{array}$ & $\begin{array}{c}\text { \% Survival } \\
\text { relative to } \\
\text { high insulin }\end{array}$ \\
\hline Nothing & $22.4 \pm 0.7$ & 0 \\
Insulin $(5 \mu \mathrm{g} / \mathrm{ml})$ & $65.0 \pm 0.7$ & 100 \\
IGF-1 $(50 \mathrm{ng} / \mathrm{ml})$ & $65.2 \pm 1.5$ & 100 \\
IGF-2 $(50 \mathrm{ng} / \mathrm{ml})$ & $64.5 \pm 1.4$ & 99 \\
& & 92 \\
NT-3 $(5 \mathrm{ng} / \mathrm{ml})$ & $61.6 \pm 4.3$ & 65 \\
CNTF $(50 \mathrm{ng} / \mathrm{ml})$ & $50.3 \pm 1.2$ & 66 \\
LIF $(50 \mathrm{ng} / \mathrm{ml})$ & $50.4 \pm 2.6$ & 64 \\
IL-6 $(50 \mathrm{ng} / \mathrm{ml})$ & $49.6 \pm 5.2$ &
\end{tabular}

Approximately 10,000 purified oligodendrocytes were plated in triplicate in 96-well Falcon plates in $100 \mu \mathrm{l}$ of B-S medium without insulin, containing a plateau concentration of the appropriate factor. After 3 days of culture, the percentage of cells surviving in each well was determined using the MTT assay (see Materials and methods). The results shown are means \pm s.e.m. of at least 3 separate experiments.

$0.8 \mathrm{ng} / \mathrm{ml}$ for IGF-1 (and truncated-IGF-1, not shown), and about $8 \mathrm{ng} / \mathrm{ml}$ for IGF-2 (Fig. 1A), as expected if both IGFs promote survival by binding to IGF-1 receptors (Sara and Hall, 1990). The $\mathrm{ED}_{50}$ for insulin-induced survival was about $20 \mathrm{ng} / \mathrm{ml}$, and the dose-response curve was very broad, extending over $2 \log$ units (Fig. 1A), suggesting that insulin promotes survival by activating at least two receptors, presumably insulin and IGF-1 receptors (Sara and Hall, 1990).

\section{Effects of NT-3 on oligodendrocyte survival in vitro}

The neurotrophins nerve-growth factor (NGF), brainderived growth factor (BDNF), NT-3 and neurotrophin-4 (NT-4) have been shown to promote the survival of various nerve cells (Barde, 1990). We tested NGF, BDNF, and NT-3 and found that NT-3, but not NGF or BDNF, promoted oligodendrocyte survival in the absence of other trophic factors. Plateau concentrations of NT-3 were almost as effective as insulin or IGF-1 (Table 1), and, ED50 was $27 \mathrm{pg} / \mathrm{ml}$ (Fig. 1B).

\section{Effects of CNTF, LIF and IL-6 on oligodendrocyte survival in vitro}

We showed previously that CNTF induces oligodendrocyte precursors in culture to express the astrocyte-specific protein GFAP (Hughes et al., 1988; Lillien et al., 1988). As shown in Table 1, CNTF is also a survival factor for purified oligodendrocytes in culture. As CNTF, LIF, and IL-6 belong to a family of homologous cytokines (Patterson, 1992), we next studied the effects of LIF and IL-6 on oligodendrocyte survival. Both factors promoted the survival of purified oligodendrocytes. Plateau concentrations of CNTF, LIF, or IL- 6 promoted the survival of about $50 \%$ of the purified oligodendrocytes for 3 days, and thus were about $65 \%$ as effective as IGF-1 or high concentrations of insulin (Table 1). The concentrations that promoted half-maximal survival were $10 \mathrm{pg} / \mathrm{ml}$ for CNTF, $300 \mathrm{pg} / \mathrm{ml}$ for LIF, and $1.5 \mathrm{ng} / \mathrm{ml}$ for IL-6 (Fig. 1C). 
A
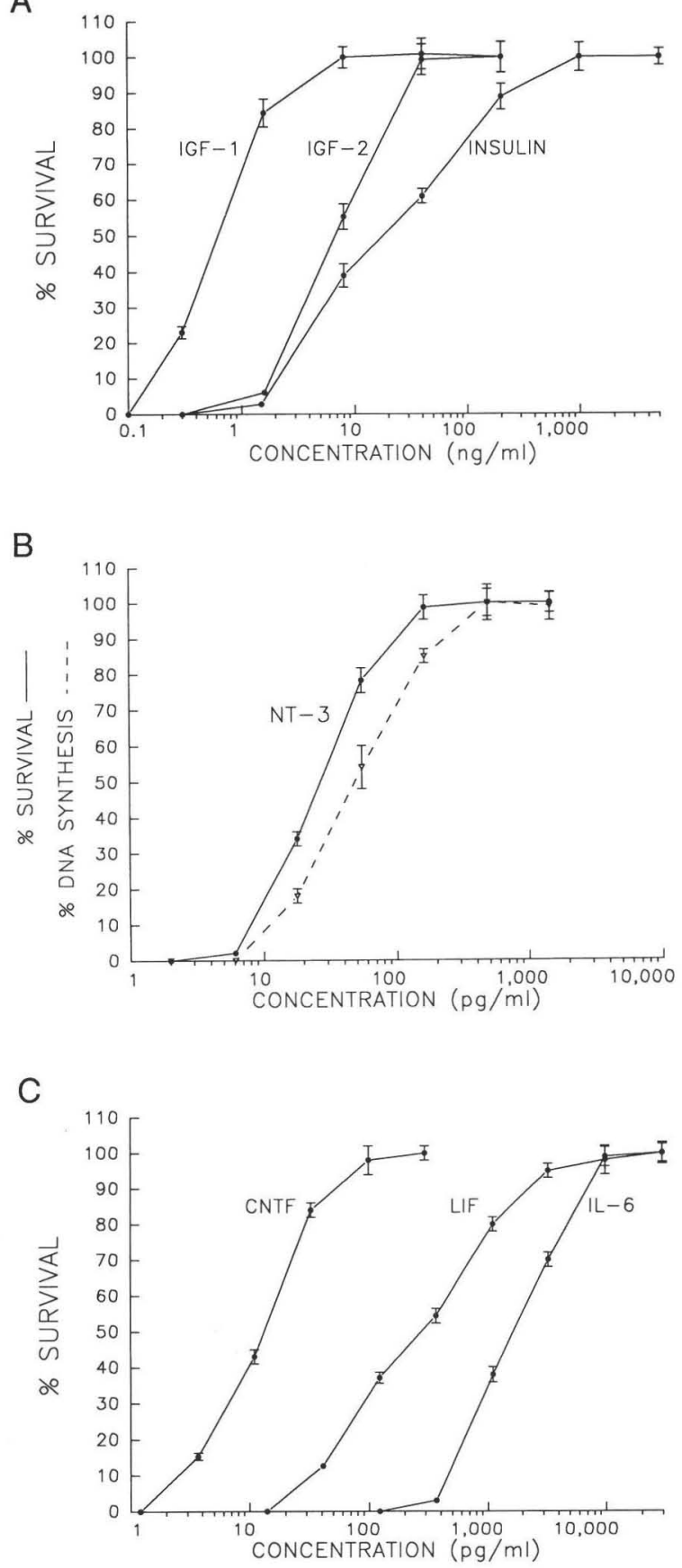

Fig. 1. Dose-response curves for seven trophic factors that promote oligodendrocyte survival in vitro. Oligodendrocytes were purified from postnatal rat optic nerves and cultured in serum-free B-S medium containing different concentrations of the trophic factor. Survival was assessed after 3 days by the MTT assay and is expressed as the means \pm s.e.m. of three cultures. Three families of trophic factors are shown: (A) IGF-1, IGF-2 and insulin; (B) NT3; (C) CNTF, LIF, and IL-6. In B, DNA synthesis by oligodendrocyte precursor cells in response to NT-3 is also shown (dashed line). The percentages of cells in each well that incorporated BrdU were determined using immunohistochemistry. The survival and DNA synthesis values in this figure are expressed as a percent of the plateau survival for each factor; unnormalized values are shown in Tables 1 and 2 and in the other Figs.
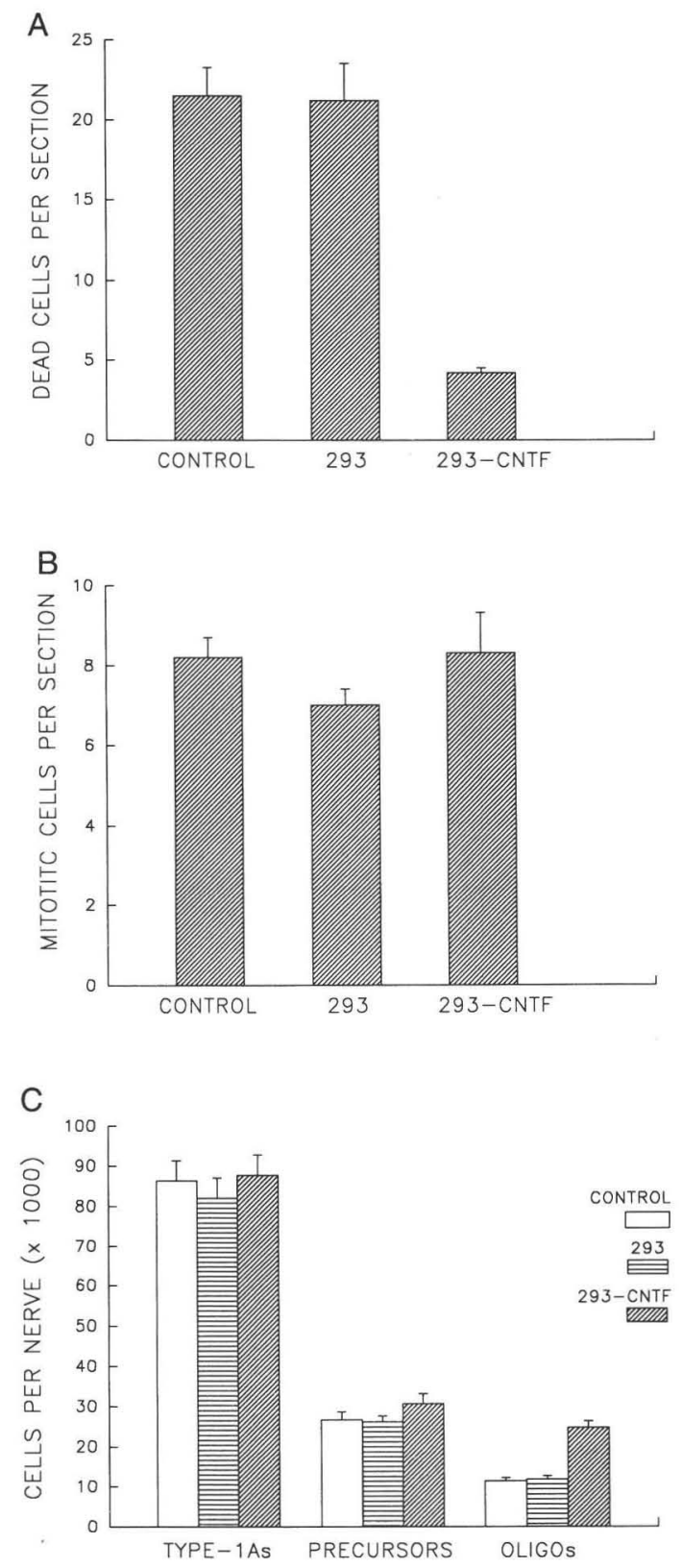

Fig. 2. The effect of increasing the concentration of CNTF in the developing optic nerve. Control 293 cells or 293 cells that had been stably transfected with a plasmid expression vector encoding a secreted form of rat CNTF, were injected into the subarachnoid space of postnatal rats at P4, and the optic nerves were examined at P8. Values represent the means \pm s.e.m. of 4 animals. (A) The number of dead cells per longitudinal section of optic nerve (stained with propidium iodide) was determined in animals that received no cells, untransfected 293 cells, or CNTF-expressing 293 cells. (B) The number of mitotic figures per longitudinal section was determined in the three groups of animals. (C) The number of cells of each type per optic nerve was determined in the three groups of animals by dissociating the cells and determining immunohistochemically the percentage of astrocytes, oligodendrocyte precursor cells, and oligodendrocytes. These immunohistochemical values were multiplied by the total number of cells per nerve (determined by DNA measurement) to give the number of each cell type per nerve. 


\section{Effect of CNTF on oligodendrocyte survival in vivo}

We previously found that the majority of dead cells in the normal developing rat optic nerve are newly formed oligodendrocytes and that delivery of exogenous PDGF could decrease this naturally occurring cell death and increase the
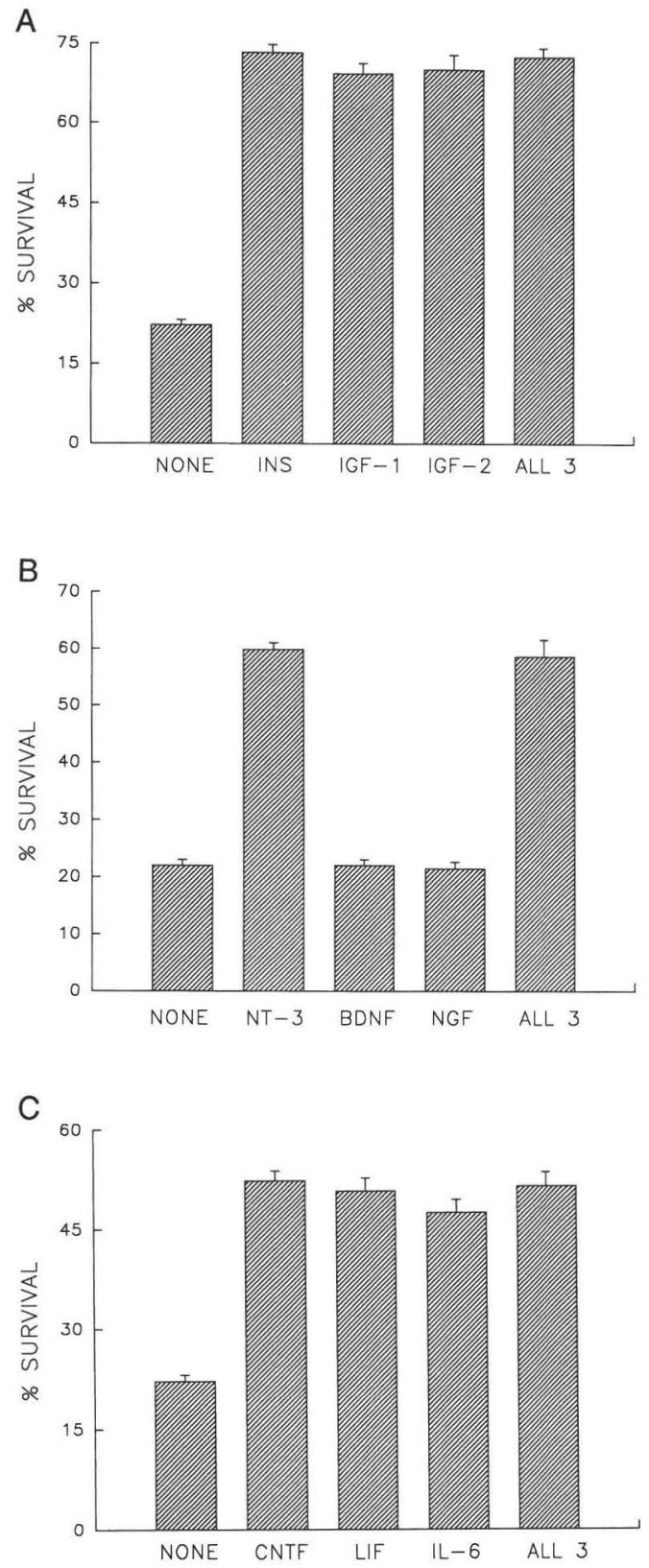

Fig. 3. The effects of combining survival factors within a class on short-term oligodendrocyte survival in culture. The survival of purified oligodendrocytes was assessed using the MTT assay after three days in culture. In this and the following two figures, plateau concentrations of each of the trophic factors in a class were used, both individually and in combination, and survival is expressed as means \pm s.e.m. of three cultures. (A) Survival in no protein factors, insulin, IGF-1, IGF-2, or all three together. (B) Survival in no protein factors, NT-3, BDNF, NGF or all three together. (C) Survival in no protein factors, CNTF, LIF, IL-6 or all three together. number of surviving oligodendrocytes. To determine whether CNTF could similarly inhibit normal oligodendrocyte death in vivo, we delivered extra CNTF into the developing rat optic nerve by implanting 293 cells that were stably transplanted with a cDNA encoding a secreted form of CNTF into the subarachnoid space of P4 rats. After 4 days, we studied the number of dead cells in frozen section of the optic nerve. Before implanting the transfected 293 cells, we showed that culture medium conditioned by them had survival activity, but no mitogenic activity, for purified optic nerve oligodendrocyte precursor cells in vitro, as assessed by the MTT assay and BrdU incorporation, respectively, while medium conditioned by untransfected 293 cells had neither activity (not shown).

The average number of dead cells per optic nerve section was decreased by about $80 \%$ in animals that had received injections of 293 cells expressing CNTF, but was unaffected in the control animals that received untransfected cells (Fig. 2A). The average number of mitotic figures per section, however, was similar in control and test animals (Fig. 2B). Thus the delivery of CNTF inhibited cell death but did not seem to influence cell proliferation in the optic nerve.

The total number of cells, determined by measuring the amount of DNA, was increased by about 16,000 cells per nerve in the CNTF-treated nerves compared with normal or control animals (Fig. 2C). To determine which cell types contributed to this increase, optic nerves were dissociated and stained with various cell type-specific antibodies: whereas the numbers of $\mathrm{GFAP}^{+}$type- 1 astrocytes or $\mathrm{A}^{2} \mathrm{~B}^{+}$oligodendrocyte precursor cells were not changed by CNTF delivery, the number of $\mathrm{GC}^{+}$oligodendrocytes was increased more than 2-fold (Fig. 2C). (About 5\% of the oligodendrocyte precursor cells in the CNTF-treated animals were $\mathrm{GFAP}^{+}$versus less than $1 \%$ in control animals). This increase of about 13,000 oligodendrocytes per nerve thus accounted for most of the increase in total number of cells per optic nerve determined from the amount of DNA.

\section{Effects of multiple factors on short-term oligodendrocyte survival}

Because single factors did not promote $100 \%$ survival of oligodendrocytes, even for three days (Table 1), we investigated whether combinations of the factors would improve short-term survival. The factors fell into three classes: (1) insulin, IGF-1 and IGF-2, (2) NT-3, BDNF, and NGF, and (3) CNTF, LIF, and IL-6. Combinations of plateau concentrations of two or three factors from within a class did not give a significantly better survival than the individual factors alone (Fig. 3). The combination of insulin, IGF-1 and IGF-2, for example, did not promote survival better than insulin, IGF-1 or IGF-2 alone (Fig. 3A). Similarly, the combination of NT-3, BDNF and NGF was not better than NT-3 alone (Fig. 3B) and the combination of CNTF, LIF and IL-6 did not improve survival over the individual factors alone (Fig. 3C).

In contrast, a combination of plateau concentration of factors from different classes almost always produced additive effects on survival (Fig. 4). Insulin plus CNTF, for 
example, was better than insulin or CNTF alone; insulin plus CNTF plus NT-3 was better than any two of these alone (Fig. 4A). The same was true for IGF-1, LIF and NT3 (Fig. 4B). Surprisingly, although BDNF did not promote survival on its own or in combination with insulin, the combination of BDNF plus CNTF (with or without insulin) promoted survival better than CNTF alone: after 7 days in culture, for instance, the percentage of oligodendrocytes surviving in insulin $(5 \mu \mathrm{g} / \mathrm{ml})$ was $17.2 \pm 2.0$, in CNTF (5 $\mathrm{ng} / \mathrm{ml}$ ) plus insulin was $46.4 \pm 1.5$, in BDNF ( $50 \mathrm{ng} / \mathrm{ml}$ ) was $16.8 \pm 0.8$ and in BDNF plus CNTF plus insulin was $80.1 \pm 1.7$.

\section{Effects of multiple factors on long-term oligodendrocyte survival in vitro}

Although single factors could promote the short-term survival (for 3 days) of as many as $70 \%$ of purified oligodendrocytes, the percentage of surviving cells rapidly fell off with increasing time in culture. No single factor pro-
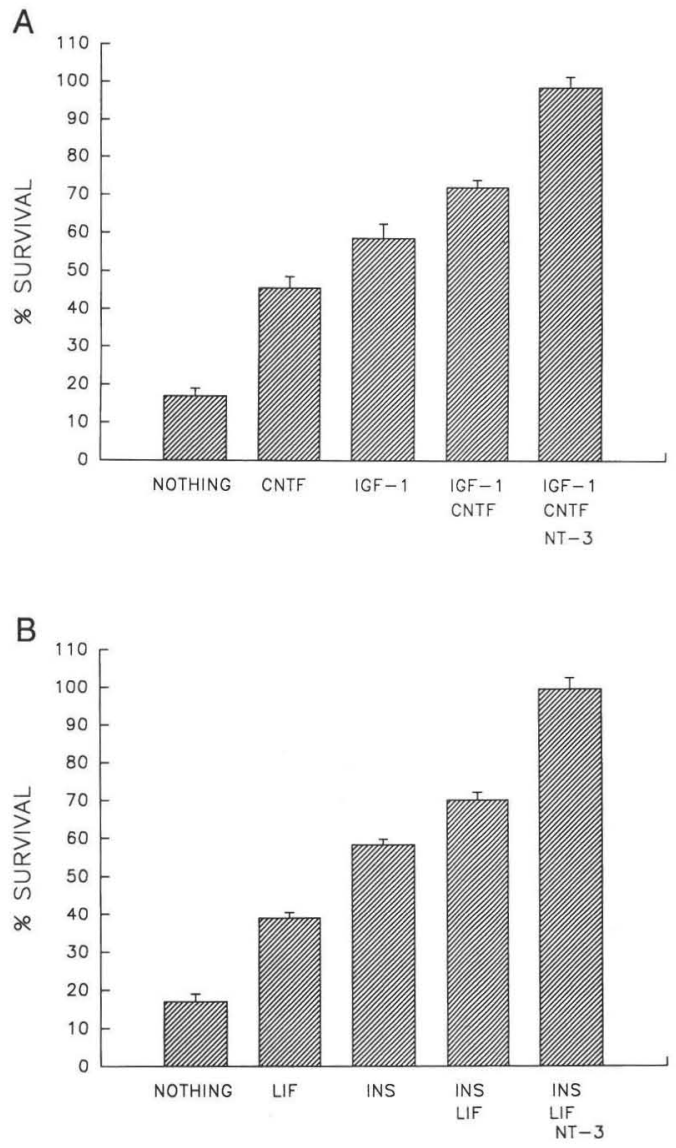

Fig. 4. The effects of combining survival factors from different classes on short-term oligodendrocyte survival in culture. The survival of purified oligodendrocytes was assessed using the MTT assay after 3 days in culture. (A) Survival in CNTF, IGF-1, IGF-1 plus CNTF, or IGF-1 plus CNTF and NT-3. (B) Survival in LIF, insulin, LIF plus insulin, or LIF plus insulin plus NT-3. Note that in this experiment, the purified cells studied were newly formed oligodendrocytes and thus were 1 day older that the purified oligodendrocyte precursor cells used in the experiment shown in Fig. 3 (see Materials and methods).
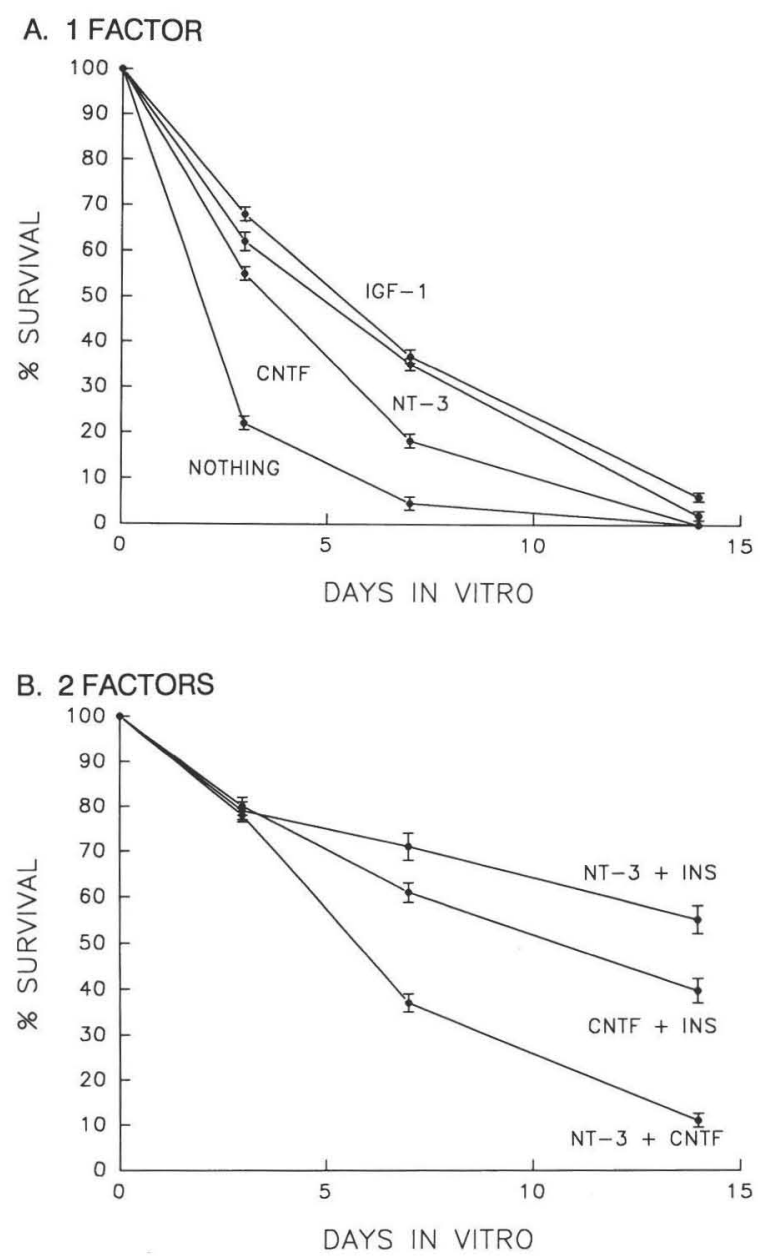

C. 3 FACTORS

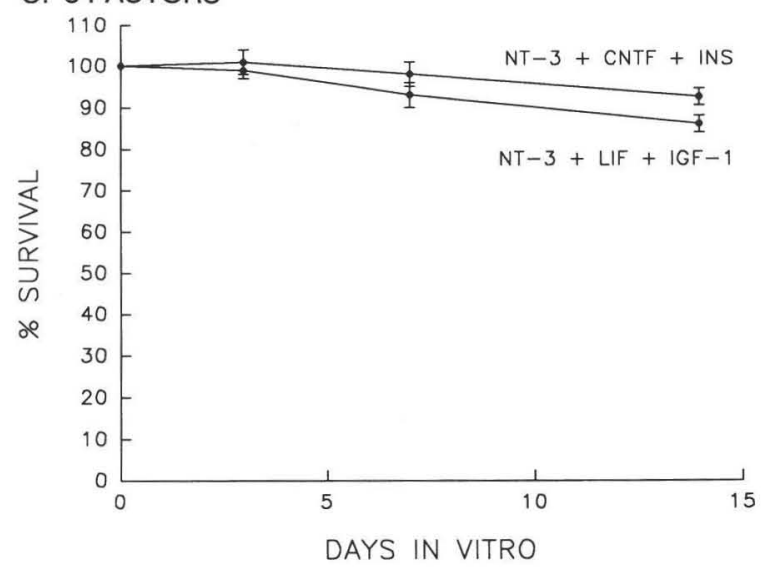

Fig. 5. The effects of combining one factor from each of the three classes on long-term oligodendrocyte survival in culture. The survival of purified oligodendrocytes was assessed using the MTT assay after 3, 7 and 14 days of culture. (A) Survival in medium containing single trophic factors is compared with the survival in medium lacking any of these factors. Results with insulin $(5 \mu \mathrm{g} / \mathrm{ml})$ do not differ significantly from those obtained with IGF-1 (not shown). (B) Survival in medium containing a combination of two factors from different classes. (C) Survival in medium containing a combination of three factors from different classes. 
moted the survival of more than about a third of the cells for a week or of about $10 \%$ of the cells for two weeks, and when used alone, NT-3 and IGF-1 promoted longer survival than CNTF (Fig. 5A).

Combinations of two factors from different classes, but not from the same class, promoted longer survival. The combination of NT-3 and insulin (or IGF-1) was the most effective combination of two factors, promoting the survival of about $60 \%$ of the oligodendrocytes for two weeks (Fig. 5B).

About $90-95 \%$ of the oligodendrocytes survived for 2 weeks or longer, when one factor from each of the three classes were combined (Fig. 5C). Although we did not quantitate the effect, it was apparent that cells cultured for 1-2 weeks in the presence of multiple trophic factors were larger and had more processes than cells grown in single factors (Fig. 6).

\section{Effects of the three classes of protein survival factors on oligodendrocyte precursor DNA synthesis and differentiation in vitro}

To determine whether any of the protein factors that promoted oligodendrocyte survival would also influence the proliferation of oligodendrocytes or their precursors, we tested their ability to induce DNA synthesis using a BrdU incorporation assay. As previously demonstrated (Barres et al., 1992), insulin, IGF-1 and IGF-2 did not induce BrdU incorporation into purified oligodendrocyte precursor cells. The same was true for CNTF, LIF, IL-6, NGF, and BDNF
(Table 2), regardless of whether or not insulin was present (not shown). NT-3, however, did promote BrdU incorporation into purified oligodendrocyte precursor cells, but only in the presence of insulin (Table 2). The concentration that promoted half-maximal BrdU incorportation was $45 \mathrm{pg} / \mathrm{ml}$ (Fig. 1B). Although NT-3 (in the presence of insulin) produced less BrdU incorporation than PDGF-AA, plateau concentrations of the two factors together acted more than additively (Table 2). Moreover, threshold concentrations of PDGF-AA and NT-3 together acted synergistically: PDGFAA at $350 \mathrm{pg} / \mathrm{ml}$ and NT-3 at $10 \mathrm{pg} / \mathrm{ml}$, which individually induced $2.6 \pm 0.7$ and $1.6 \pm 0.5$ percent of oligodendrocyte precursor cells to incorporate BrdU, respectively, together induced 23.2 \pm 1.0 percent of the cells to incorporate BrdU.

To study whether any of these factors influence the differentiation of oligodendrocyte precursor cells in vitro, we studied their effects on the differentiation of precursor cells into either $\mathrm{GC}^{+}$oligodendrocytes or $\mathrm{GFAP}^{+}$type- 2 astrocytes. As shown in Table 2, none of the factors were required for differentiation into $\mathrm{GC}^{+}$oligodendrocytes and none of them inhibited this differentation, the way that basic FGF has been shown to do (Bogler et al., 1990; McKinnon et al., 1990). CNTF and LIF each induced about $5 \%$ of the purified precursor cells to express GFAP weakly after 24 hours in culture (not shown; the effect of IL-6 was not examined); this response was much weaker than that previously elicited in the presence of other optic nerve cell types (Lillien et al., 1988; Lillien and Raff, 1990). NT-3 did not induce GFAP expression (not shown).
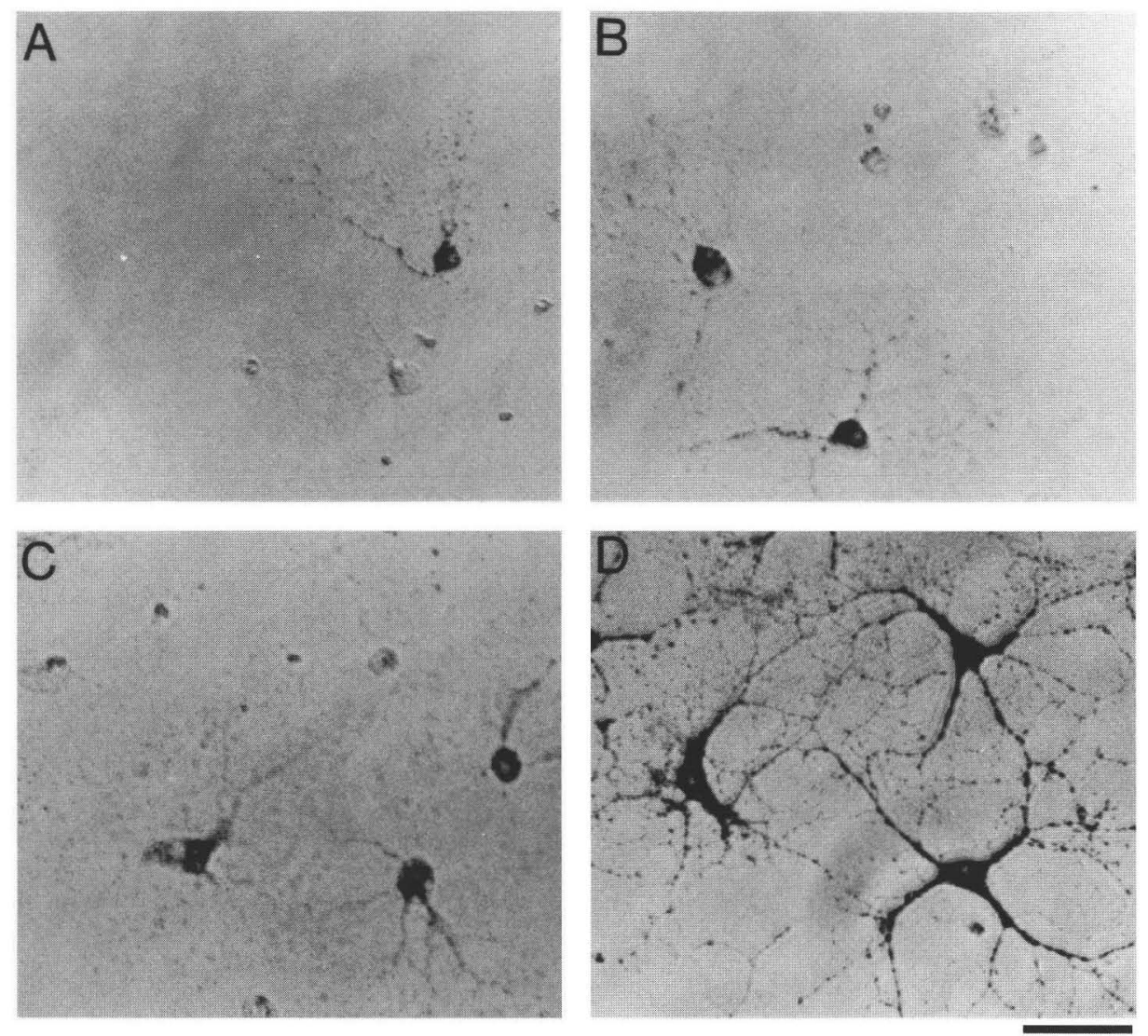

Fig. 6. Morphology of oligodendrocytes assayed with MTT after 7 days in culture. Purified oligodendrocytes were cultured in serum-free B-S medium containing (A) no added protein factors, (B) insulin $(5 \mu \mathrm{g} / \mathrm{ml})$; (C) a combination of insulin and CNTF ( $5 \mathrm{ng} / \mathrm{ml})$, or (D) a combination of insulin, CNTF, and NT-3 $(5 \mathrm{ng} / \mathrm{ml})$. Cells were labelled with MTT for 1 hour. The MTT is cleaved by viable cells to form an insoluble, dark reaction product. Bar, $40 \mu \mathrm{m}$. 
Table 2. BrdU incorporation and differentiation of purified oligodendrocyte precursor cells in culture

\begin{tabular}{lcc}
\hline Factor & $\%$ BrdU $^{+}$cells & $\% \mathrm{GC}^{+}$cells \\
\hline Nothing & 0 & 100 \\
Insulin $(5 \mu \mathrm{g} / \mathrm{ml})$ & 0 & 100 \\
& & 100 \\
CNTF $(50 \mathrm{ng} / \mathrm{ml})$ & 0 & 100 \\
LIF $(50 \mathrm{ng} / \mathrm{ml})$ & 0 & 100 \\
IL-6 $(50 \mathrm{ng} / \mathrm{ml})$ & 0 & 100 \\
NGF $(100 \mathrm{ng} / \mathrm{ml})$ & 0 & 100 \\
BDNF $(50 \mathrm{ng} / \mathrm{ml})$ & 0 & 100 \\
& & $81 \pm 2$ \\
NT-3 $(5 \mathrm{ng} / \mathrm{ml})$ & 0 & $61 \pm 3$ \\
NT-3+insulin & $15 \pm 1$ & $25 \pm 1$ \\
PDGF AA $(10 \mathrm{ng} / \mathrm{ml})$ & $37 \pm 2$ & $3 \pm 0.3$ \\
PDGF+NT-3+insulin & $71 \pm 2$ &
\end{tabular}

Approximately 10,000 purified oligodendrocyte precursor cells were plated in 96-well Falcon plates in $100 \mu \mathrm{l}$ of B-S medium without insulin, containing the appropriate factor. After 1 day of culture, $\operatorname{BrdU}(10 \mu \mathrm{M})$ was added to each well for 17 hours. The percentages of cells in each well that incorporated $\mathrm{BrdU}$ or that differentiated into oligodendrocytes were determined using immunohistochemistry (see Materials and methods). The results shown are means \pm s.e.m. of 3 cultures.

\section{Comparison of the concentration of PDGF-AA required for cell survival with the concentration required for DNA synthesis}

Oligodendrocyte precursor cells express the PDGF alphareceptor (Hart et al., 1989b; Pringle et al., 1992), which can be activated by all three forms of PDGF: PDGF-AA, PDGF-BB, and PDGF-AB (Heldin et al., 1988). Previously, we found that PDGF-AA promotes the survival of oligodendrocyte precursors and newly formed oligodendrocytes, but not of more mature oligodendrocytes, both in vitro and in vivo. In the present study, we compared the effects of different concentrations of PDGF-AA on the survival and DNA synthesis of purified oligodendrocyte precursor cells in culture. Surprisingly, the concentration of PDGF-AA that supported half-maximal survival $\left(\mathrm{ED}_{50}\right)$ was $8 \mathrm{pg} / \mathrm{ml}$, which was more than 200 times lower than the $\mathrm{ED}_{50}$ for DNA synthesis, which was $1850 \mathrm{pg} / \mathrm{ml}$ (Fig. 7A). When an oligodendrocyte precursor-like cell line, CG-4 (Louis et al., 1992), was tested, however, the PDGF dose-response curve for DNA synthesis (ED50 of $1850 \mathrm{pg} / \mathrm{ml}$ ) was similar to the PDGF dose-response curve for survival (ED50 of $800 \mathrm{pg} / \mathrm{ml}$; Fig. 7B). For both purified oligodendrocyte precursor cells and CG-4 cells, plateau concentrations of PDGF supported the survival of about $65 \%$ to $100 \%$ of the cells for 3 days. These findings raised the possibility that there are two types of PDGF receptors, a high affinity one that supports the survival of oligodendrocyte precursor cells and a lower affinity one that supports both the survival and proliferation of these cells, and that CG-4 cells only express the latter receptors, while normal oligodendrocyte precursor cells express both.

To test this possibility further, we studied the ability of PDGF-BB to support surival and induce DNA synthesis in purified oligodendrocyte precursor cells. As shown in Fig. 7C, PDGF-BB promoted half-maximal DNA synthesis at $5,555 \mathrm{pg} / \mathrm{ml}$ and half-maximal survival at $700 \mathrm{pg} / \mathrm{ml}$ (Fig.
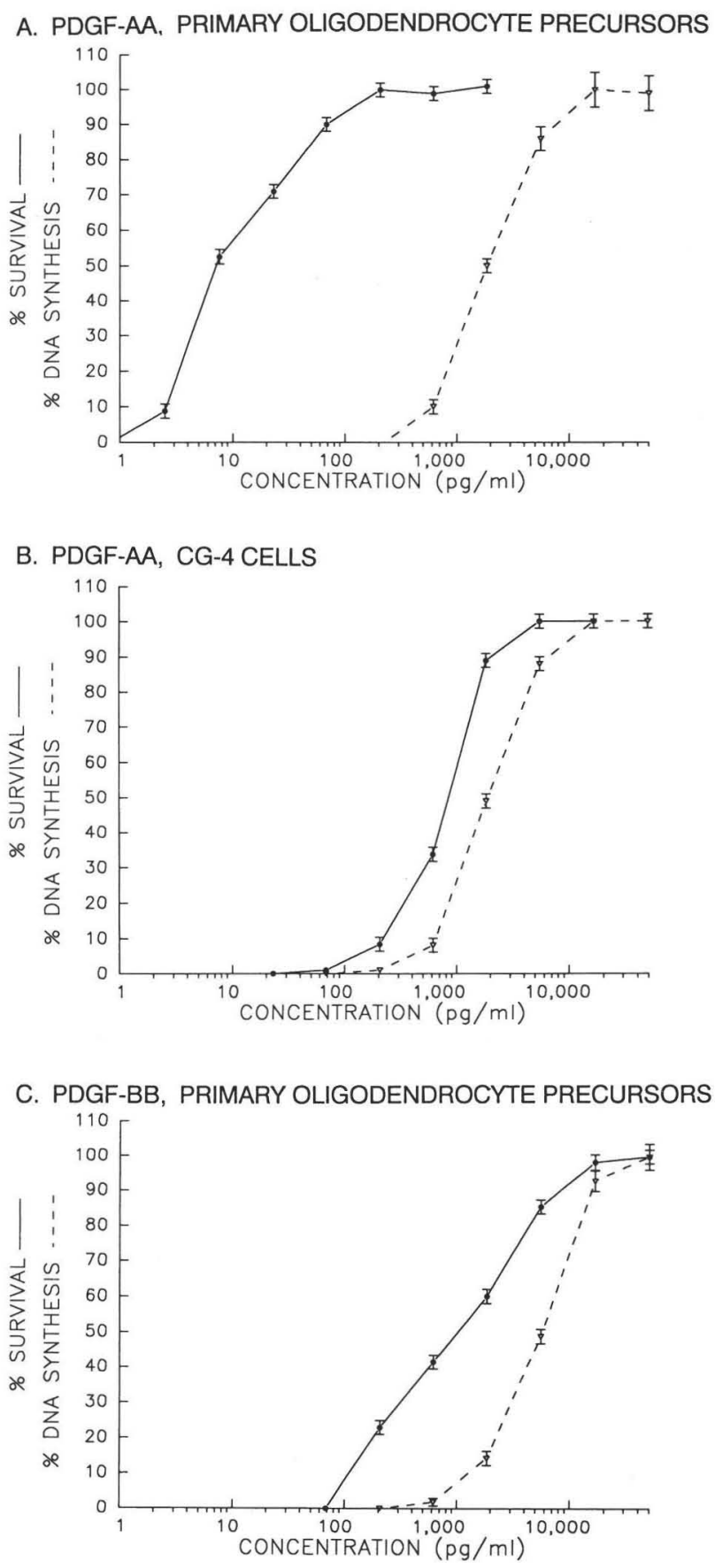

Fig. 7. Survival and DNA synthesis responses of oligodendrocyte precursor cells and CG-4 cells to varying concentrations of PDGF. Oligodendrocyte precursors were purified from postnatal rat optic nerves and cultured in serum-free B-S medium containing different concentrations of the trophic factor. Survival was assessed after 3 days by the MTT assay. DNA synthesis was measured after 2 days by asssaying BrdU incorporation using immunohistochemistry. The results are expressed as the means \pm s.e.m. of three cultures. All survival and DNA synthesis values are expressed as a percentage of the plateau value for each factor; unnormalized survival values were typically about $65 \%$ and unnormalized DNA synthesis values were about $40 \%$ for the purified precursors and about $95 \%$ for the CG-4 cells. (A) The effect of PDGF-AA on purified oligodendrocyte precursor cells. (B) The effect of PDGF-AA on CG-4 cells. (C) The effect of PDGF-BB on purified oligodendrocyte precursor cells. 
Table 3. Effects of three mitogens on survival, DNA synthesis, and differentiation of purified oligodendrocyte precursor cells in culture

\begin{tabular}{|c|c|c|c|}
\hline & PDGF & NT-3 & bFGF \\
\hline $\begin{array}{l}\text { Promotes survival } \\
\text { of oligodendrocyte precursors } \\
\text { of oligodendrocytes }(>2 \mathrm{~d} \text { old })\end{array}$ & $\begin{array}{l}\text { Yes } \\
\text { No }\end{array}$ & $\begin{array}{l}\text { Yes } \\
\text { Yes }\end{array}$ & $\begin{array}{l}\text { No } \\
\text { No }\end{array}$ \\
\hline $\begin{array}{l}\text { Promotes DNA synthesis by } \\
\text { oligodendrocyte precursor cells } \\
\text { in high insulin }(5 \mu \mathrm{g} / \mathrm{ml}) \\
\text { without insulin }\end{array}$ & $\begin{array}{l}\text { Yes } \\
\text { Yes }\end{array}$ & $\begin{array}{l}\text { Yes } \\
\text { No }\end{array}$ & $\begin{array}{l}\text { Yes } \\
\text { No }\end{array}$ \\
\hline $\begin{array}{l}\text { Promotes DNA synthesis by } \\
\text { oligodendrocytes (in high insulin) }\end{array}$ & No & No & Yes \\
\hline $\begin{array}{l}\text { Inhibits differentiation of } \\
\text { oligodendrocyte precursor cells } \\
\text { into } \mathrm{GC}^{+} \text {oligodendrocytes }\end{array}$ & No & No & Yes \\
\hline $\begin{array}{l}\text { The table summarizes observations } \\
\text { Barres et al. (1992); in all cases, the } \\
\text { immunopanning and were greater tha }\end{array}$ & $\begin{array}{l}\text { the pre } \\
\text { vere isol }\end{array}$ & $\begin{array}{l}\text { t paper } \\
d \text { by sec }\end{array}$ & \\
\hline
\end{tabular}

7C). The ED50 for PDGF-BB-induced DNA synthesis was 3 times higher than the $\mathrm{ED}_{50}$ for PDGF-AA-induced DNA synthesis, as expected since PDGF-BB has a slightly lower affinity for PDGF alpha receptors than does PDGF-AA (Heldin et al., 1988). In contrast, PDGF-BB was about 100 times less potent in promoting the survival of oligodendrocyte precursor cells than PDGF-AA. These results suggest that oligodendrocyte precursor cells express a novel high affinity form of the PDGF receptor that promotes survival and prefers PDGF-AA to PDGF-BB by a factor of 100.

Although newly formed oligodendrocytes do not divide in response to PDGF-AA, they still express PDGF receptors (Hart et al., 1989a,b). To test whether they still express the very high affinity PDGF receptor, we studied the ability of different concentrations of PDGF-AA to promote their survival. A concentration of $200 \mathrm{pg} / \mathrm{ml}$ supported their survival as effectively as a concentration of $50 \mathrm{ng} / \mathrm{ml}$ (not shown), indicating that they do express the high affinity form of the receptor. Because newly formed oligodendrocytes do not divide in response to PDGF-AA, binding studies will be required to determine whether these cells also still express low-affinity receptors.

\section{- DISCUSSION}

\section{Multiple signalling proteins promote the survival of oligodendrocytes in culture}

Our findings indicate that IGFs are not sufficient on their own to promote long-term survival of oligodendrocytes in vitro and suggest that multiple signals are required for oligodendrocyte survival in vivo. Long-term survival of purified oligodendrocytes in serum-free culture could only be achieved by a combination of protein survival factors that belong to at least three classes: (1) insulin, IGF-1, and IGF-2, (2) neurotrophins, particularly NT-3, and (3) CNTF, LIF, and IL-6. We have thus identified seven signalling pro- teins that can promote oligodendrocyte survival in vitro and it seems likely that many more will be discovered. In culture at least, all three classes of factors seem to promote oligodendrocyte survival by inhibiting programmed cell death, as without them the cells die with the characteristic morphological features of apoptosis (Barres et al., 1992). Many of these factors are found in the developing optic nerve, including IGF-1 (Hannson et al., 1989), IGF-2 (Sara and Carlsson-Skwarut, 1990), CNTF (Stockli et al., 1991), and possibly NT-3 (Ceccatelli et al., 1991), where they are likely to be present in limiting amounts, as $50 \%$ of newly formed oligodendrocytes in the developing optic nerve normally die, and these deaths can be inhibited by delivery of exogenous trophic factors, such as PDGF (Barres et al., 1992) and, as shown in the present study, CNTF.

Although the serum-free B-S medium used in the in vitro experiments described here contained three non-protein signalling molecules (thyroxine, tri-iodothyronine, and progesterone), only progesterone promoted oligodendrocyte survival in vitro, and it did so only weakly (see Materials and methods). This survival effect of progesterone is interesting in view of the findings of Baulieu and his colleagues that glial cell cultures make progesterone (Jung-Testas et al., 1989a,b) and oligodendrocytes in culture contain progesterone receptors (Jung-Testas et al., 1991).

\section{The activation of either the insulin receptor or the IGF-1 receptor promotes oligodendrocyte survival}

We previously found that a high concentration of insulin, which is sufficient to activate IGF-1 receptors, promotes oligodendrocyte survival. Our present results indicate that insulin also promotes the survival of oligodendrocytes by binding to its own receptors: it promotes half-maximal survival at $20 \mathrm{ng} / \mathrm{ml}$, which is sufficient to bind to insulin receptors but not IGF-1 receptors (Sara and Hall, 1990). Insulin receptors have previously been shown to be expressed by oligododendrocytes and their precursors (Baron-vanEvercooren et al., 1991), as have IGF-1 receptors (McMorris et al., 1986; McMorris and Dubois-Dalcq, 1988). On other cell types, insulin receptors are thought to mediate the various metabolic actions of insulin and are not generally thought to promote survival (Sara and Hall, 1990). It seems unlikely that insulin normally promotes oligodendrocyte survival in vivo, as it is not thought to cross the blood-brain barrier or to be synthesized in the CNS.

Our dose-response curves suggest that the survival effects of IGF-1 and IGF-2, as well as of high concentrations of insulin, are all mediated by IGF-1 receptors (Sara and Hall, 1990), which probably explains why these factors are not additive in promoting oligodendrocyte survival. None of these factors on their own stimulate DNA synthesis in oligodendrocyte or their precursor cells. As IGF-1 and IGF- 2 are present in the developing and adult CNS (Rotwein et al., 1988; Lievre et al., 1991; Hannson et al., 1989; Sara and Carlsson-Skwarut, 1990), they are likely to promote the survival of developing oligodendrocytes in vivo.

\section{CNTF, LIF, and IL-6 promote oligodendrocyte survival}

Although CNTF, LIF, and IL-6 each promote the survival 
of oligodendrocytes and their precursors in vitro, they are only about $65 \%$ as effective as high insulin or IGF-1. Similar observations have recently been made by others (M. Noble, personal communication; Louis et al., 1993). We show here that CNTF can also promote oligodendrocyte survival in vivo: the delivery of exogenous CNTF into the developing rat optic nerve decreases the number of dead oligodendrocytes by $80 \%$ and approximately doubles the number of oligodendrocytes that develop over the 4 day period of the experiment. CNTF and LIF have already been shown to support the survival of several types of neurons in vitro, including ciliary ganglion neurons and motor neurons (Barbin et al., 1984; Arakawa et al., 1990; Sendnter et al., 1991; Martinou et al., 1992), and the concentrations that promote the survival of neurons are similar or identical to the concentrations that support oligodendrocytes. CNTF has also been shown to promote the survival of motor neurons in vivo (Sendnter et al., 1990; Oppenheim et al., 1991).

Although CNTF is synthesized by optic nerve astrocytes (Stockli et al., 1991), it is unlikely to be available normally to oligodendrocytes in vivo: it lacks a secretory signal sequence and is not secreted by cells in vitro (Stockli et al., 1989). LIF and IL-6, by contrast, have secretory signal sequences and are secreted, but it is not known whether they are normally present in white matter or optic nerve. LIF is expressed in certain brain regions (Yamamori, 1991), however, and astrocytes can secrete IL-6 and LIF in vitro (reviewed by Patterson and Fann, 1992). LIF, like CNTF, can induce oligodendrocyte precursor cells to express GFAP and so the paucity of $\mathrm{GFAP}^{+}$cells of the oligodendrocyte cell lineage in the developing optic nerve (Fulton et al., 1991) suggests either that sufficient amounts of CNTF or LIF are not normally available in vivo, or that extracellular-matrix-bound signals that have been shown to collaborate with CNTF in inducing stable GFAP expression in vitro are not available, even though they are present in the nerve (Lillien et al., 1990).

CNTF would, however, be expected to be released after injury to astrocytes (Rudge et al., 1985; Lillien et al., 1988), and thus it is likely to promote the survival of oligodendrocytes in the injured CNS. Delivery of exogenous CNTF into the brain might be able to promote the survival of injured oligodendrocytes in demyelinating diseases, just as it promotes motor neuron survival both after axotomy (Sendnter et al., 1990) and in mutant mice with progressive motor neuronopathy (Sendnter et al., 1992).

Why are the effects of CNTF, LIF and IL-6 in promoting oligodendrocyte survival not additive? Unlike the case of insulin and the IGFs, this finding cannot be explained by an action on a common receptor: the $\mathrm{ED}_{50}$ for oligodendrocyte survival for each factor closely corresponds with the binding affinity for their respective receptors on other cell types (Huber et al., 1992; Hilton and Nicola, 1992; Van-Snick, 1990), suggesting that CNTF, LIF and IL-6 receptors are all present on oligodendrocytes, . Instead, the lack of additive effects most likely reflects the sharing of a common signal-transducing subunit by the three receptors (Ip et al., 1992; Taga et al., 1992), which may therefore promote survival by activating the same intracellular signalling pathways.
As in the case of insulin, the broad shape of the LIF dose-response curve suggests that LIF may promote survival by an action on two different receptors. High and low affinity binding sites for LIF have recently been reported (Hilton and Nicola, 1992), with $\mathrm{K}_{\mathrm{dS}}$ of about $50 \mathrm{pM}$ and 1 $\mathrm{nM}$, respectively. The two receptors may be distinguished by the presence or absence of one of the the LIF receptor subunits.

Neither CNTF, nor LIF, nor IL-6 induce DNA synthesis in purified oligodendrocytes or their precursor cells. This contrasts with the recent demonstration by Louis et al. (1992) that IL-6 promotes the proliferation of CG-4 cells, an oligodendrocyte-precursor cell line.

\section{NT-3 promotes oligodendrocyte survival and oligodendrocyte precursor cell proliferation}

NT-3 promotes the short-term survival of oligodendrocytes almost as effectively as high insulin or IGFs and it also stimulates DNA synthesis in oligodendrocyte precursor cells. To our knowledge, this is the first evidence that CNS glial cells respond to neurotrophins. NT-3 promotes the proliferation of neural crest cells (Kalcheim et al., 1992) and the survival of DRG neurons from 8-day-old chick embryos (Gotz et al., 1992), and the $\mathrm{ED}_{50}$ s for neuronal and oligodendrocyte survival are nearly identical.

Of the factors we have tested that have a secretory signal sequence, NT-3 is the single most potent oligodendrocyte survival factor. It is also the most potent mitogen for oligodendrocyte precursor cells, being about 10 times more potent than PDGF in inducing DNA synthesis, although NT-3 requires IGFs (or a high concentration of insulin) for this effect, whereas PDGF does not. Thus NT-3 may well be among the factors that normally act in vivo to promote the survival of oligodendrocytes and the survival and proliferation of their precursors.

But is NT-3 available to oligodendrocytes in vivo? NT3 mRNA has been observed by in situ hybridization in glial cells in sections of optic nerve and other white matter tracts (Ceccatelli et al., 1991). In that study NT-3 mRNA was detected only after colchicine pretreatment and it is not clear if this increased the sensitivity of detection or promoted the expression of mRNAs that would not otherwise have been expressed. NT-3 mRNA is expressed by neurons in many brain regions (Schecterson and Bothwell, 1992; Ernfors et al., 1992), and we have found that neurons promote both the survival of oligodendrocytes and the proliferation of their precursor cells in the developing optic nerve (Barres et al., unpublished data; Barres and Raff, 1993). Cerebellar interneurons in vitro secrete a non-PDGF mitogen for oligodendrocyte precursor cells (Levine, 1989; Gard and Pfeiffer, 1990), which may well be NT-3, as cerebellar granule neurons have been shown to make NT-3 mRNA (Ernfors et al., 1992; Schecterson and Bothwell, 1992). Thus, NT-3 may be involved in neuron-glial interactions, as well as in neuorn-neuron interactions.

NT-3 is the third mitogen for oligodendrocyte precursor cells to be identified. The others are bFGF (Bogler et al., 1990) and PDGF (Noble et al., 1988; Richardson et al., 1988). Interestingly, they all have different effects on cells of the oligodendrocyte lineage, as reviewed in Table 3.

In contrast to NT-3, which on its own promotes oligo- 
dendrocyte survival in vitro, BDNF promotes oligodendrocyte survival only when combined with CNTF. Similarly, chick motorneurons in vitro are not saved by BDNF, but are responsive to BDNF in vivo (Oppenheim et al., 1992). It seems that a cell's sensitivity to BDNF is regulated by extrinsic factors both in vitro and in vivo.

\section{PDGF-AA may promote oligodendrocyte precursor cell survival by activating a novel high- affinity receptor}

Perhaps the most surprising finding of the present study is that the concentration of PDGF-AA that promotes halfmaximal survival of oligodendrocyte precursor cells is more than 200-fold lower than the half-maximal concentration that promotes DNA synthesis in these cells. In contrast, the ED50s of NT-3 for survival and proliferation of oligodendrocyte precursor cells only differs by several-fold. The dramatically different dose-response curves for PDGF-induced survival and DNA synthesis raises the possibility that there are two types of PDGF receptors on oligodendrocyte precursors: a low-affinity receptor that mediates both proliferation and survival and a high affinity receptor that mediates survival only. Two of our observations are consistent with this possibility. First, the high affinity survival response is not seen with PDGF-BB, even though PDGF$\mathrm{BB}$ binds almost as well to the PDGF alpha-receptor (Heldin et al., 1988) and is almost as effective as PDGFAA in inducing DNA synthesis in these cells. Second, the PDGF-AA dose-response for survival promotion and DNA synthesis induction are not very different when the CG-4 oligodendrocyte precursor cell line is studied. The simplest interpretation of these results is that normal oligodendrocyte precursor cells express two PDGF receptors, one with high affinity that promotes survival and prefers PDGF-AA to PDGF-BB by a factor of 100 or so, and one with lower affinity that promotes both survival and proliferation and prefers PDGF-AA to PDGF-BB by a factor of only 3, and that CG-4 cells appear to have mainly the low affinity receptor.

Previously, oligodendrocyte precursor cells were shown to express PDGF alpha-receptor protein (Hart et al., 1989a,b) and mRNA (Pringle et al., 1992), but not PDGF beta-receptors. While, these studies did not exclude the possible presence of small numbers of beta-receptors, the presence of both alpha- and beta-receptors could not account for our observations, as PDGF-AA does not bind to PDGF beta-receptors (Heldin et al., 1988). Thus, our data suggest that oligodendrocyte precursor cells express two forms of the PDGF alpha-receptor, a standard alpha-receptor and a novel, very high affinity receptor, the nature of which is unknown.

The presence on newly formed oligodendrocytes and their precursors of high affinity PDGF receptors that mediate survival but not proliferation responses to PDGF could have important implications for the behavior of these cells in vivo. A low concentration of PDGF in vivo, for example, could promote the survival of the oligodendrocyte precursors without promoting their proliferation. This could help to explain why oligodendrocyte precursor cells in the adult optic nerve express PDGF alpha-receptors (Pringle et al., 1992) but seem to divide only slowly (G. Wolswijk, personal communication; ffrench-Constant and Raff, 1986): concentrations of PDGF may be low in the adult nerve or the adult precursor cells may preferentially express the high-affinity form of the PDGF receptor. Such receptors could also explain the failure of newly formed oligodendrocytes to divide in response to PDGF, even though they continue to express PDGF alpha-receptors for a day or more (Hart et al., 1989b) and the receptors can still be activated by PDGF so as to increase intracellular $\mathrm{Ca}^{2+}$ (Hart et al., 1989a) and nuclear fos expression (Hart et al., 1992) and to promote cell survival (Barres et al., 1992; and this paper); while this may reflect the presence of a downstream block to proliferation, as previously suggested (Hart et al., 1989a, 1992), it may instead reflect the selective loss of the lowaffinity form of the PDGF receptor, which mediates proliferation.

\section{Can long-term survival of any cell type be achieved by a single trophic factor?}

Our results indicate that NT-3, CNTF, and IGF-1 can act together to promote the long-term survival of the majority of oligodendrocytes in vitro. These findings are strikingly similar to those of Arakawa et al. (1990), who found that multiple factors collaborate to promote the long-term survival of enriched chick embryonic motoneurons in vitro: FGF and CNTF individually promoted survival of about half of the motoneurons, whereas together they saved $100 \%$ of them. These authors also found that, in contrast to the oligodendrocytes, IGF-1 had little effect on its own, although it acted additively with either CNTF or FGF to save motorneurons. In the case of motoneurons, it is not clear if the additive effects of FGF and CNTF are explained by the presence of subsets of motoneurons with different survival requirements or by the combined action of both factors on the same cell. In the case of oligodendrocytes, which are probably more homogeneous than motorneurons, it is unlikely that the additive effects of NT-3, CNTF, and IGF-1 are explained by the presence of oligodendrocyte subsets.

Our failure so far to find a single factor that is able on its own to promote long-term oligodendrocyte survival in vitro does not mean that such a factor does not exist. On the other hand, among cells that have been shown to require survival factors, we are not aware of any example where a single signalling molecule on its own permits long-term survival in culture. Motoneurons, for example, require multiple factors (as described above), including laminin (Dohrman et al., 1986; Sendnter et al., 1991), some DRG neurons require insulin, progesterone, and serum, in addition to NGF (Bottenstein et al., 1980), and purified retinal ganglion cells require a combination of at least four signalling proteins (unpublished observations). Although there are few examples of primary cell types that have been purified sufficiently to assess adequately their survival requirements in vitro, it seems possible that all cells require multilple survival factors for long-term survival.

The identification of three classes of extracellular signalling proteins that additively promote oligodendrocyte survival raises several questions. Do all three classes of factors normally promote oligodendrocyte survival in vivo, and if so, which members of each class are most important? Are 
there more classes? Which classes of survival factors depend on axons for their production or release? Does the existence of three classes of survival factors imply that there are at least three intracellular signalling pathways that can act to promote survival, and, if so, where do the pathways converge?

We thank R. Kolbeck and Y. A. Barde for supplying the recombinant neurotrophins, M. Lake at Kabi Pharmacia/Kabigen in Stockholm for supplying the recombinant human IGFs and J. Heath for supplying the recombinant mouse LIF, and J. C. Louis for providing the CG-4 cell line. B. A. Barres is supported by a fellowship from the US National Multiple Sclerosis Society and is a Schering-Plough Fellow of the Life Sciences Research Foundation.

\section{REFERENCES}

Arakawa, Y., Sendtner, M. and Thoenen, H. (1990). Survival effect of ciliary neurotrophic factor (CNTF) on chick embryonic motoneurons in culture: comparision with other neurotrophic factors and cytokines. $J$. Neurosci. 10, 3507-3515.

Barbin, G., Manthorpe, M. and Varon, S. (1984). Purification of the chick eye ciliary neurotrophic factor. J. Neurochem. 43, 1468-1478.

Barde, Y. A. (1989). Trophic factors and neuronal survival. Neuron 2, 1525-34.

Barde, Y. A. (1990). The nerve growth family. Prog. Growth Factor Res. 2 , 237-48.

Barde, Y. A., Edgar, D. and Thoenen, H. (1982). Purification of a new neurotrophic factor from mammalian brain. EMBO J. 1, 549-553.

Baron-Van Evercooren, A., Olichon-Berthe, C., Kowalski, A., Visciano, G. and VanObberghen, E. (1991). Expression of IGF-I and insulin receptor genes in the rat central nervous system: a developmental, regional, and cellular analysis. J. Neurosci. Res. 28, 244-253.

Barres, B. A., Hart, I. K., Coles, H. S. R., Burne, J. F. Voyvodic, J. T., Richardson, W. D. and Raff, M. C. (1992). Cell death and control of cell survival in the oligodendrocyte lineage. Cell 70, 31-46.

Barres, B. A. and Raff M. C. (1993). Proliferation of oligodendrocyte precursor cells depends on electrical activity in axons. Nature 361, 258260.

Bartlett, P. F., Noble, M. D., Pruss, R. M., Raff, M. C., Rattray, S. and Williams, C. A. (1981). Rat neural antigen-2 (RAN-2): A cell surface antigen on astrocytes, ependymal cells, Muller cells and lepto-meninges defined by a monoclonal antibody. Brain Res. 204, 339-351.

Biggers, J. D., Whitten, W. K. and Whittingham, D. G. (1971). The culture of mouse embryos in vitro. In Methods in Mammalian Embryology (ed. J. C. Daniel), pp. 86-116. San Francisco: Freeman.

Bogler, O., Wren, D., Barnett, S., Land, H. and Noble, M. (1990). Cooperation between two growth factors promotes extended self renewal and inhibits differentiation of oligodendrocyte-type-2 astrocyte (O-2A) progenitor cells. Proc. Natl. Acad. Sci. USA 87, 6368-6372.

Bottenstein, J. E. and Sato, G. H. (1979). Growth of a rat neuroblastoma cell line in serum-free supplemented medium. Proc. Natl. Acad. Sci. USA 76, 514-517.

Bottenstein, J. E., Skaper, S. D., Varon, S. S. and Sato, G. H. (1980). Selective survival of neurons from chick embryo sensory ganglionic dissociates utilizing serum-free supplemented medium. Exp. Cell Res. 125, 183-190.

Brunk, C. F., Jones, K. C. and James, T. W. (1979). Assay for nanogram quantities of DNA in cellular homogenates. Analyt. Biochem. 92, 497500 .

Ceccatelli, S., Ernfors, P., Villar, M. J. Persson, H. and Hokfelt, T. (1991). Expanded distribution of mRNA for nerve growth factor, brainderived neurotrophic factor, and neurotrophin 3 in the rat brain after colchicine treatment. Proc. Natl. Acad. Sci. USA 88, 10352-10356.

Cohen, J. J. (1991). Programmed cell death in the immune system. Adv. Immunol. 50, 55-85.

Dohrmann, U., Edgar, D. and Thoenen, H. (1986). Muscle-derived factors that support survival and promote fiber outgrowth from embryonic chick spinal motor neurons in culture. Dev. Biol. 118, 209-221.
Eisenbarth, G. S., Walsh, F. S. and Nirenburg, M. (1979). Monoclonal antibodies to a plasma membrane antigen of neurons. Proc. Natl. Acad. Sci. USA 76, 4913-6.

Ernfors, P., Merlio, J. P. and Persson, H. (1992). Cells expressing mRNA for neurotrophins and their receptors during embryonic rat development. Eur. J. Neurosci. 3, 953-961.

ffrench-Constant, C. and Raff, M. C. (1986). Proliferating bipotential glial progenitor cells in adult rat optic nerve. Nature 319, 499-502.

Fulton, B. P., Burne, J. F. and Raff, M. C. (1991). Glial cells in the rat optic nerve: The search for the type-2 astrocyte. Ann. NY Acad. Sci. 633, 27-34.

Gard, A. L. and Pfeiffer, S. E. (1990). Two proliferative stages of the oligodendrocyte lineage under different mitogenic control. Neuron $\mathbf{5}$, 615-625.

Gotz, R., Kolbeck, R., Lottspeich, F. and Barde, Y. A. (1992). Production and characterization of recombinant mouse neurotrophin-3. Eur. J. Biochem. 204, 745-749.

Gratzner, H. G. (1982). Monoclonal antibody to 5-bromo- and 5iododeoxyuridine:a new reagent for detection of DNA replication. Science 318, 474-475.

Hannson, H. A., Holmgren, A., Norstedt, G. and Rosell, B. (1989). Changes in the distribution of insulin-like growth factor I, thioredoxin, thioredoxin reductase and ribonucleotide reductase during the development of the retina. Exp. Eye Res. 48, 411-420.

Hart, I. K., Richardson, W. D., Bolsover, S. R. and Raff, M. C. (1989a). PDGF and intracellular signaling in the timing of oligodendrocyte differentiation. J. Cell Biol. 109, 3411-17.

Hart, I. K., Richardson, W. D., Heldin, C.-H., Westermark, B. and Raff, M. C. (1989b). PDGF receptors on cells of the oligodendrocyte-type-2 astrocyte (O-2A) cell lineage. Development 105, 595-603.

Hart, I. K., Richardson, W. D. and Raff, M. C. (1992). PDGF increases the expression of fos and jun in newly formed oligodendrocytes that have become resistant to the mitogenic effect of PDGF. Glia $\mathbf{6}, 310-313$.

Heldin, C. H., Backstrom, G., Ostman, A., Hammacher, A., Ronnstrand, L., Rubin, K., Nister, M. and Westermark, B. (1988). Binding of different dimeric forms of PDGF to human fibroblasts:evidence for two separate receptor types. EMBO J. 7, 13871393.

Hilton, D. J. and Nicola, N. A. (1992). Kinetic analyses of the binding of leukemia inhibitory factor to receptor on cells and membranes in detergent solution. J. Biol. Chem. 267, 10238-47.

Huber, J., Thoenen, H. and Sendtner, M. (1992). Characterisation of a high and low affinity receptor for CNTF. Soc. Neurosci. Abstr. 276.1.

Hughes, S. M., Lillien, L. E., Raff, M. C., Rohrer, H. and Sendtner, M. (1988). Ciliary neurotrophic factor induces type-2 astrocyte differentiation in culture. Nature 335, 70-73.

Ip, N. Y., Nye, S. H., Boulton, T. G., Davis, S., Taga, T., Li, Y., Birren, S. J. and Yancopoulus, G. D. (1992). CNTF and LIF act on neuronal cells via shared signalling pathways that involve the IL-6 signal transducing receptor component gp130. Cell 69, 1121-32.

Jung-Testas, I., Hu, Z. Y., Baulieu, E. E. and Robel, P. (1989a). Steroid synthesis in rat brain cell cultures. J. Steroid Biochem. 34, 199-204.

Jung-Testas, I., Hu, Z. Y., Baulieu, E. E. and Robel, P. (1989b). Neurosteroids: biosynthesis of pregnenolone and progesterone in primary cultures of rat glial cells. Endocrinol. 125, 2083-2091.

Jung-Testas, I., Renoir, J. M., Gasc, J. M. and Baulieu, E. E. (1991). Estrogen-inducible progesterone receptor in primary cultures of rat glial cells. Exp. Cell Res. 193, 12-19.

Kalcheim, C., Carmeli, C. and Rosenthal, A. (1992). Neurotrophin 3 is a mitogen for cultured neural crest cells. Proc. Natl. Acad. Sci. USA 89, 1661-1665.

Koury, M. J. and Bondurant, M. C. (1990). Erythropoeitin retards DNA breakdown and prevents programmed cell death in erythroid progenitor cells. Science $\mathbf{2 4 8}$, 378-81.

Krypianou, N. and Issacs, J. T. (1988). Activation of programmed cell death in the ventral prostate after castration. Endocrinol. 122, 552-562.

Levi-Montalcini, R. (1987). The nerve growth factor: 35 years later. EMBO J. 6, 1145-1154.

Levine, J. M. (1989). Neuronal influences in glial progenitor cell development. Neuron 3, 103-113.

Lievre, C. A., Stahlbom, P. A. and Sara, V. R. (1991). Expression of IGF1 and -2 mRNA in the brain and craniofacial region of the rat fetus. Development 111, 105-115.

Lillien, L. E., Sendtner, M., Rohrer, H. , Hughes, S. M. and Raff, M. C. 
(1988). Type-2 astrocyte development in rat brain cultures is initiated by a CNTF-like protein produced by type 1 astrocytes. Neuron 1, 485-494.

Lillien, L. E. and Raff, M. C. (1990). Analysis of the cell-cell interactions that control type-2 astrocyte development in vitro. Neuron 4, 525-534.

Lillien, L. E., Sendtner, M. and Raff, M. C. (1990). Extracellular matrixassociated molecules collaborate with ciliary neurotrophic factor to induce type-2 astrocyte development. J. Cell Biol. 111, 635-644.

Louis, J. C., Magal, E., Muir, D., Manthorpe, M. and Varon, S. (1992). CG-4, a new bi-potential glial cell line from rat brain, is capable of differentiation in vitro into either mature oligodendrocytes of type-2 astrocytes. J. Neurosci. Res. 31, 193-204.

Louis, J. C., Magal, E., Takayama, S. and Varon, S. (1992). Differential effects of CNTF, LIF, and IL-6 on oligodendrocyte-type-2 astrocyte progenitor cells. Soc. Neurosci. Abstr. 467.10.

Louis, J. C., Magal, E., Takayama, S. and Varon, S. (1993). CNTF protection of oligodendrocytes against natural and tumor necrosis factorinduced death. Science 259, 689-692.

Maguad, J. P., Sargent, I. and Mason, D. Y. (1988). Detection of human white cell proliferative responses by immunoenzymatic measurement of bromodeoxyuridine uptake. J. Immunol. Meth. 106, 95-100.

Martin, D. P., Schmidt, R. E., DiStefano, P. S., Lowry, O. H., Carter, J. G. and Johnson, E. M., Jr (1988). Inhibitors of protein synthesis and RNA synthesis prevent neuronal death caused by nerve growth factor deprivation. J. Cell Biol. 106, 829-844.

Martinou, J. C., Martinou, I. and Kato, A. C. (1992). Cholinergic differentiation factor (CDF/LIF) promotes survival of isolated rat embryonic motoneurons in vitro. Neuron 8, 737-744.

McKinnon, R. D., Matsui, T., Dubois-Dalcq, M. and Aaronson, S. A. (1990). FGF modulates the PDGF-driven pathway of oligodendrocyte development. Neuron 5, 603-614.

McMorris, F. A. and Dubois-Dalcq, M. (1988). Inuslin-like growth factor I promotes cell proliferation and oligodendroglial commitment in rat glial progenitor cells developing in vitro. J. Neurosci. Res. 21, 199-209.

McMorris, F. A., Smith, T. M., DeSalvo, S. and Furlanetto, R. W. (1986). Insulin-like growth factor I/somatomedin C: a potent inducer of oligodendrocyte development. Proc. Natl. Acad. Sci. USA 83, 822-826.

Mosmann, T. (1983). Rapid colorimetric assay for cellular growth and survival: application to proliferation and cytotoxicity assays. J. Immunol. Meth. 65, 55-63.

Noble, M., Murray, K., Stroobant, P., Waterfield, M. D. and Riddle, P. (1988). PDGF promotes division and motility and inhibits premature differentiation of the oligodendrocyte-type-2 astrocyte progenitor cell. Nature 333, 560-562.

Oppenheim, R. W., Prevette, D., Qin-Wei, Y., Collins, F. and MacDonald, J. (1991). Control of embryonic motoneuron survival in vivo by ciliary neurotrophic factor. Science 251, 1616-1618.

Oppenheim, R. W., Qin-Wei, Y., Prevette, D. and Yan, Q. (1992). Brainderived neurotrophic factor rescues developing avian motoneurons from cell death. Nature 360, 755-757.

Patterson, P. H. (1992). The emerging neuropoietic cytokine family. Curr. Opin. Neurobiol. 2, 94-97.

Patterson, P. H. and Fann, M. J. (1992). Further studies of the distribution of CDF/LIF mRNA. Ciba Fdn. Sym. 167, 124-140.

Pringle, N., Mudhar, H. S., Collarini, E. J. and Richardson, W. D. (1992). Expression of PDGF-alpha receptors in the rat CNS appears to be restricted to glial cells of the oligodendrocyte lineage. Development $\mathbf{1 1 5}$, 535-551.

Pruss, R. (1979). Thy-1 antigen on astrocytes in long-term cultures of rat central nervous system. Nature $\mathbf{3 0 3}, 390-396$.

Purves, D. (1988). Body and Brain, A Trophic Theory of Neural Connections. Cambridge, MA: Harvard.

Raff, M. C. (1992). Social controls on cell survival and death: an extreme view. Nature 356, 397-400.

Raff, M. C., Miller, R. H. and Noble, M. (1983). A glial progenitor cell that develops in vitro into an astrocyte or an oligodendrocyte depending on culture medium. Nature 303, 390-396.
Ranscht, B., Clapshaw, P. A., Price, J., Noble, M. and Seifert, W. (1982). Development of oligodendrocytes and Schwann cells studied with a monoclonal antibody against galactocerebroside. Proc. Natl. Acad. Sci. USA 79, 2709-2713.

Richardson, W. D., Pringle, N., Mosley, M. J., Westermark, B. and Dubois-Dalcq, M. (1988). A role for platelet-derived growth factor in normal gliogenesis in the central nervous system. Cell 53, 309-319.

Rotwein, P., Burgess, S. K., Milbrandt, J. D. and Krause, J. (1988). Differential expression of insulin-like growth factor genes in rat central nervous system. Proc. Natl. Acad. Sci. USA 85, 265-269.

Rudge, J. S., Manthorpe, M. and Varon, S. (1985). The output of neuronotrophic and neurite-promoting agents from rat brain astroglial cells: a microculture method for screening potential regulatory molecules. Dev. Brain Res. 19, 161-172.

Sara, V. R. and Carlsson-Skwirut, C. (1990). The role of the insulin-like growth factors in the central nervous system: biosynthesis and biological role. In Growth Factors: From Genes to Clincal Application, (ed. V. R. Sara), pp. 179-191. New York: Raven Press.

Sara, V. R. and Hall, K. (1990). Insulin-like growth factors and their binding proteins. Physiol. Rev. 70, 591-614.

Schecterson, L. C. and Bothwell, M. (1992). Novel roles for neurotrophins are suggested by BDNF and NT-3 mRNA expression in developing neurons. Neuron $9,449-463$.

Sendnter, M., Arakawa, Y., Stockli, K. A., Kreutzberg, G. W. and Thoenen, H. (1991). Effect of ciliary neurotrophic factor (CNTF). on motoneuron survival. J. Cell Sci. Suppl. 15, 103-109.

Sendtner, M., Kreutzberg, G. W. and Thoenen, H. (1990). Ciliary neurotrophic factor prevents the degeneration of motor neurons after axotomy. Nature $345,440-441$.

Sendtner, M., Schmalbruch, H., Stockli, K. A., Corroll, P., Kreutzberg, G. W. and Thoenen, H. (1992). Ciliary neurotrophic factor prevents degeneration of motor neurons in mouse mutant progressive motor neuronopathy. Nature 358, 502-504.

Sommer, I. and Schachner, M. (1981). Monoclonal antibodies (O1 to O4) to oligodendrocyte cell surfaces: an immunocytochemical study in the central nervous system. Dev. Biol. 83, 311-327.

Sommer, I. and Schachner, M. (1982). Cells that are O4-antigen positive and $\mathrm{O} 1$ - negative differentiate into O1-positive oligodendrocytes. Neurosci. Let. 29, 183-188.

Stockli, K. A., Lillien, L. E., Noher-Noe, M., Breitfeld, G., Hughes, R. A., Raff, M. C., Thoenen, H. and Sendnter, M. (1991). Regional distribution, developmental changes, and cellular localization of CNTFmRNA and protein in the rat brain. J. Cell Biol. 115, 447-459.

Stockli, K. A., Lottspeich, F., Sendnter, M., Masiakowski, P., Carroll, P., Gotz, R., Lindholm, D. and Thoenen, H. (1989). Molecular cloning, expression and regional distribution of rat ciliary neurotrophic factor. Nature 342, 920-923.

Taga, T., Narazaki, M., Yasukawa, K., Saito, T., Miki, D., Hamaguchi, M., Davis, S., Shoyab, M., Yancopoulos, G. D. and Kishimoto, T. (1992). Functional inhibition of hematopoietic and neurotrophic cytokines by blocking the interleukin 6 signal transducer gp 130. Proc. Natl. Acad. Sci. USA 89, 10998-11001.

Van Snick, J. (1990). Interleukin-6: An overview. Ann. Rev. Immunol. 8, 253-278.

Williams, G. T., Smith, C. A., Spooncer, E., Dexter, T. M. and Taylor, D. R. (1990). Haemopoietic colony stimulating factors promote cell survival by suppressing apoptosis. Nature 343, 76-78.

Wyllie, A. H., Morris, R. G., Smith, A. L. and Dunlop, D. (1984). Chromatin cleavage in apoptosis: association with condensed chromatin morphology and dependence on macromolecular synthesis. J. Pathol. $142,67-77$.

Yamamori, T. (1991). Localization of cholinergic differentiation factor/leukemia inhibitory factor mRNA in the rat brain and peripheral tissues. Proc. Natl. Acad. Sci. USA 88, 7298-7302.

(Accepted 2 March 1993) 